\title{
Susceptibility to respiratory infections associated with CD8alpha chain mutation
}

INSERM

\section{Source}

INSERM. (1999). Orphanet: an online rare disease and orphan drug data base.

Susceptibility to respiratory infections associated with CD8alpha chain mutation.

ORPHA:169085

Susceptibility to respiratory infections associated with CD8 alpha chain mutation is a rare primary immunodeficiency due to a defect in adaptive immunity characterized by the absence of CD8+ $T$ cells with normal immunog lobulin and specific antibody titres in blood and susceptibility to recurrent respiratory bacterial and viral infections. Symptom severity range from fatal respiratory insufficiency to mild or asymptomatic phenotypes. 